\title{
Dying for Security
}

\section{BRUCE BUCHAN}

GRIFFITH UNIVERSITY

\section{-THE PROBLEM OF IN/SECURITY}

On 4 December 2008 Australia's then prime minister, Kevin Rudd, proclaimed the First National Security Statement to the Australian Parliament. The statement begins with a crucial claim: 'The first priority of government is the nation's security.' $\mathrm{A}$ repeated definite article in this sentence reveals that this claim is not primarily about the Rudd government's priorities, nor is it simply about Australia's security. This is a universal claim; a political philosophical proposition that the 'first priority' of any and all governments is the security of 'the nation' it governs. This is not a claim unheard of in the history of political thought nor is its obvious pre-eminence here unique. Security is obviously a 'highly divisive and isolationist concept' in the sense that those 'secured' and those still 'insecure' are to be isolated one from the other. ${ }^{2}$ I will argue here, however, that the divisiveness of the concept originates in an ontology of the subject of security that is well established in Western political thought. 
The modern preoccupation with security may be said to have crystallised in Thomas Hobbes's (1588-1679) classic work of political philosophy, Leviathan (1651). Leviathan is a work drenched in fear and insecurity, but it was not this alone that alienated contemporary, and fascinated subsequent, readers. ${ }^{3}$ Hobbes's argument for awesome sovereignty as the only reliable guarantor of security was couched in terms of a contract between subjects to establish sovereignty and this, along with some unorthodox religious doctrines, made his work seem a danger to, rather than a defence of, princely prerogatives. Indeed, as I have elsewhere argued, Hobbes's contract entailed that his was a peculiarly disembodied sovereign. No longer the time-worn personification of an eternal 'body politic', Hobbes's sovereign was an 'artificiall person' made by mutual contract for mutual security, but subject to perennial insecurity and even to death. ${ }^{4}$

Hobbes underscored the fear of insecurity animating his political thought with an arresting account of a hypothetical death scene. The likening of political entities to animate bodies and, by analogy, political disturbances to physical illnesses, was a familiar trope in Western thought. Remarkably, however, few who used the metaphor ever envisaged the actual death of the political body. This is what rendered Chapter 29 of Hobbes's Leviathan apparently familiar (in likening political problems to diseases and maladies) but also confronting. 'Though nothing can be immortall, which mortals make', Hobbes began, 'Common-wealths might be secured' by the proper use of human reason 'at least, from perishing by internall diseases'. ${ }^{5}$ Polities are 'designed', he maintained, 'to live, as long as Mankind, or as the Lawes of Nature, or as Justice it selfe ', but their construction is often so imperfect that 'hardly lasting out their own time, must assuredly fall upon the heads of their posterity'. ${ }^{6}$ When that happens 'the Common-wealth is DISSOLVED', and as the subjects are no longer able obtain security each is:

at liberty to protect himself by such courses as his own discretion shall suggest unto him. For the Sovereign, is the publique Soule, giving Life and Motion to the Common-wealth; which expiring, the Members are governed by it no more, than the Carcasse of a man, by his departed (though Immortall) Soule. ${ }^{7}$

Hobbes's death scene pictures the death of the sovereign; the sole guarantor of security, the only barrier against the permanent insecurity of the war of all against 
all in the 'state of nature'. The mortality of sovereignty threatened an immediate return to this chaotic condition. Hobbes's sovereignty embodies what I will here call the problem of in/security. The provision of security is underwritten by the perennial threat of insecurity, and its sudden reappearance (described above in Hobbes's political death scene) exposes all subjects to immanent death. Hobbes's thought thus takes shape around the central assumption that subjects in the insecure state of nature are dying for security.

In this essay I will use the phrase 'dying for security' to convey the problem of in/security. The problem is that the subject of security is moved, Hobbes suggests, by the fear of violent death represented by the spectre of the state of nature. But this is a fear that cannot be escaped. This subject is 'dying for security' because the state of nature does not end with the establishment of sovereignty. Rather, it is subsumed within and constitutes the sovereignty that exposes the subject to an even greater threat of violent death. This perpetual fear of violent death ensures that the subject of security continues to long for that which cannot be attained. I argue that the problem of in/security not only played a major role in Western political thought but was also manifested in Australian colonial history. Indeed, the problem echoes still in the key assumption of the National Security Statement that Australia's 'strength, resilience and cohesion as a nation' is tied to our 'modern, democratic and tolerant' institutions and values. ${ }^{8}$ Security is needed to protect our cohesive and democratic society from sources that apparently threaten social and/or political incoherence. This conception of 'security', however, is premised on the perennial threat of 'insecurity'.

-THE SUBJECT OF SECURITY: ON FEAR OF LIONS AND POLE-CATS

The problem of in/security lies at the heart of modern liberal political and international thought. Its origins are traceable, at least in part, to the contractual turn in early modern European thought which tied the legitimacy of government to hypothetical contracts between subjects (or between subjects and sovereigns) to trade off sovereign power for protection of person and property. In striking the terms of this deal, Thomas Hobbes came to define the condition of the modern subject as eternally beset by insecurity, perennially driven by the lure of security into the clutches of awesome sovereignty. Though Hobbes's sovereign Leviathan 
state was not universally endorsed, the terms of his contractual 'solution' to the problem of in/security was remarkably influential. Though redefined in more or less Hobbesian terms, the contract for security revealed the modern self in political thought as the subject of an unattainable quest, or an unresolvable tension between irreconcilable fears. Fearful of the insecurity at the hands of one's fellow human beings, the modern subject was also fearful of the Hobbesian 'solution' of the awesome sovereign state. In his masterwork, the Two Treatises of Government (1690), John Locke (1632-1704) expressively referred to these twin fears as akin to the fear of 'pole cats and foxes' on the one hand, and 'lions' on the other. Locke was not responding explicitly to Hobbes when he derided the bargain I have here represented in Hobbesian terms, but he might as well have been:

For if it be asked, what Security, what Fence is there in such a State [as Hobbes's Leviathan], against the Violence and Oppression of this Absolute Ruler? The very Question can scarce be born ... Betwixt Subject and Subject, they will grant, there must be Measures, laws, and Judges, for their mutual Peace and Security: But as for the Ruler, he ought to be Absolute ... As if when Men quitting the State of Nature entered into Society [by means of Hobbes's contract], they agreed that all of them but one, should be under the restraint of Laws, but that he should retain all the Liberty of the State of Nature, increased with Power, and made licentious by Impunity. This is to think Men are so foolish that they take care to avoid what Mischiefs may be done them by Pole-Cats, or Foxes, but are content, nay think it Safety, to be devoured by Lions. ${ }^{9}$

Here Locke appears to parody the Hobbesian bargain, to trade off the chance of harm from fellow subjects for the certainty of terror under an awesome sovereignty. Locke's critique (though it was not explicitly aimed at Hobbes) was that the fear of violent death inherent in the state of nature is not only transferred to Hobbes's civil state, but is massively augmented by the powers and impunity of the sovereign.

Just as revealing here as Locke's juxtaposition of lions and pole-cats, is his juxtaposition of subjects and sovereigns. Subjects are those individuals whose liberty and security is premised on the existence of sovereigns able to proclaim and enforce laws. Laws are the means by which the person and property of subjects are secured. Thus far, Locke and Hobbes would be in agreement; they differed over just 
how extensive sovereignty had to be to ensure the effectiveness of the law. The terms of their disagreement rapidly became the one of the key sources of dynamic tension in subsequent liberal political (and political philosophical) debate. Less often discussed has been the matter of their substantive agreement on the identity of the subject and the degree to which they may be said to be dying for security.

'The subject' is an ambiguous concept in British political thought. At its simplest, the term referred to all those persons who owed allegiance to the sovereign, who 'hath absolutelie in his power the authoritie of warre and peace', in return for maintaining 'gud ordur', 'cyvyle ordur' and 'pollytyke rule'.10 Thomas Hobbes developed this general notion of the subject in terms of his contractual argument for sovereign power designed to ensure the 'Peace of the Subjects within themselves, and their Defence against a common Enemy'.11 Hobbes's express purpose was to construe the relationship between sovereign and subject in such a way that the purpose of political association hinged solely on protection of life and property. As Hobbes so succinctly put it, 'Sovereigns can do no more for the citizens' happiness than to enable them to enjoy the possessions their industry has won them, safe from foreign and civil war.'12

In arguing so, Hobbes suggested that without the 'security' that comes from mutual association to enforce the certainty of 'penalties', each individual would be so motivated to seek their own advantage, to secure themselves at the expense of others (by theft, deceit, or even murder). ${ }^{13}$ It was for this reason alone that Hobbes considered sovereignty necessary. Importance was attached not to who exercised sovereignty, but that sovereignty be exercised. At every turn in the bargain, however, the subject of security is haunted by fear of violent death. The bargain is made of course because each subject fears violent death in the sovereignless state of nature. Having made the bargain, sovereignty consisted precisely in the right to inflict death through the 'power of judgement' as to when and where to exercise the right of punishment ('the sword of justice') and the right of making war or peace ('the sword of war').14

This account of sovereignty left to the subject a sphere of freedom ('corporall Liberty') consisting in whatever his or her sovereign permitted, or did not expressly forbid. It was in this latter sense that Hobbes famously defined the liberty of the subject as consisting in the 'Silence of the Law', allowing the subject freedom 'to do, 
or forebeare, according to his own discretion'.15 In so defining the subject, Hobbes argued that the subject's liberty was tied to the effectiveness of the state's sovereignty, the purpose of which was to ensure the 'Peace of the Subjects within themselves, and their Defence against a common Enemy'.16 The subject must obey the sovereign only so long as the sovereign is able to provide effective protection, and when that protection ceases, the subject returns to a 'state of nature'. In this condition, which he famously equated to the condition of 'the savage people' in America, individuals must provide for their own protection, or seek it under some other sovereign power. ${ }^{17}$

While the purpose of sovereignty was to provide protection, the mode or operation of sovereignty consisted in the twelve 'rights' Hobbes specified in Chapter 18 of Leviathan, all of which framed sovereignty as a power over (though exercised for the benefit of) subjects. Of these twelve, Hobbes insisted that the ninth right, 'of making Warre, and Peace with other Nations', was crucial because command of the armies 'without other Institution, maketh him that hath it Soveraign'.18 Crucially, Hobbes reinforced his argument with a vivid description of the chaos that would ensue if sovereignty collapsed or simply failed to develop, a life of 'continuall feare, and danger of violent death; And the life of man solitary, poore, nasty, brutish and short ...'.19 Hobbes' sovereignty then, might be thought of as 'instituted' by subjects for their own benefit, surrendering to the sovereign the right to make laws, adjudicate punishments and rewards. In the absence of such deliberate 'institution' the command of armed force alone constituted the essence of sovereign power.

John Locke, with his Two Treatises of Government (1690) is a political thinker conventionally juxtaposed to Hobbes and his Leviathan (1651). In fact, Locke responded less to Hobbes than to Robert Filmer's argument that monarchy must be thought of as instituted by god. ${ }^{20}$ Locke's political context was also different in that it was dominated not by rebellion against kingly authority as such, but by wrangles among the landed elite as to royal succession and the appropriate division of power between crown and parliament. Nonetheless, Locke contended that the liberty of the subject itself constituted sovereign power, whereas Hobbes defined the subject's liberty as an artefact of sovereignty. The power of Locke's 'political society' derived from the consent of the 'subjects' who constituted it, and was provisional on their 'rights' (life, liberty and estate) being protected and secured from infringement by 
having an independent means of adjudicating disputes. ${ }^{21}$ In fact, Locke was reticent to use the language favoured by more absolutist writers such as Hobbes, preferring instead to speak of 'men' or 'individuals' or 'persons' rather than 'subjects'; and 'supream power' rather than 'sovereignty'. Indeed, Locke insisted that seeing the 'making of War and Peace' as the defining feature of 'sovereignty' would allow any band of pirates who grouped together on oath to become 'sovereigns'. Locke argued that the making of war and peace was the prerogative of the 'Supream Power' or government of 'Politick Societies', namely those political associations established by consent for the mutual preservation of individual rights. ${ }^{22}$ Crucially, Locke tied this understanding of the provisional and delegated nature of 'Supream Power' to a historicised account of the emergence of such societies in Europe, far in advance of supposedly 'unciviliz'd' peoples in North America. ${ }^{23}$ Though far from representative of all British political thought, Locke's historicised account of 'more advanced' political societies or states as those able to protect the individual rights of its members (especially their property rights) by adjudicating disputes (through law), and to protect the whole (by means of wielding the power of war and peace) effectively sustained Hobbes's identification of insecurity with life in the state of nature.

Locke's was a significant conceptual manoeuvre, effectively translating Hobbes's hypothetical state of nature into a real existing state of nature against which Europeans could measure their own advance (civilisation). In doing so, the significance of Hobbes's hypothetical death scene took on a new dimension. For Hobbes, the hypothetical death scene embodied a potent fear, a powerful motive inherent in each and every subject of security. In picturing a veritable state of nature in America and elsewhere, Locke was able to suggest that the quest for security could be conceptualised not simply as an internal fear, but as an objective line demarcating separate zones of security and insecurity. Hobbes's hypothetical death scene is never entirely absent, for Locke still envisaged the potentially disastrous collapse of security through foreign conquest or domestic tyranny by which the civil 'State of Peace' is replaced by a 'State of War' whereon 'Dissolution and Death follows'. ${ }^{24}$ For Locke these remained real possibilities, but just as important is the new identification of a perpetual source of insecurity in the 'real existing' state of nature in America and elsewhere. In representing the problem of in/security in this 
way, it became possible for some political thinkers to argue that the 'solution' to perpetual insecurity lay at hand, in understanding and anticipating the historical development of civilization. Just as importantly, this representation of the problem of in/security identified a new fear and source of insecurity (alongside Hobbes's fear of the death of sovereignty) in the ungoverned license of 'savagery' beyond the zone of 'civilization'.

\section{-SECURITY AND THE STATE OF CIVILISATION}

The centrality of ideas of historical progress and civilization in European thought in the sixteenth and seventeenth century was reflected in Natural Law theories of social development based on the harnessing of productive labour (in manufacture and agricultural cultivation), and engagement in economic exchange or trade (typically involving money) as concomitants in the development of sovereign states as protective institutions. ${ }^{25}$ The rights of particular members of these societies were held to be secure precisely because they lived within societies based on private property and protected by systems of written law enforced by sovereign states. ${ }^{26}$ In these schemes, warfare itself came to be defined as an armed contest between sovereign states, as opposed to armed violence between private individuals. As the sixteenth-century jurist Gentili defined it, war 'is a just and public contest of arms'. ${ }^{27}$ In this pervasive view, war appears merely as an instrument of these 'public' authorities or sovereign states to be used either for conquest, liberation, or even to drive development. ${ }^{28}$ Indeed, war and violence were inherent in what may be termed the Western ontology of the subject of security, an ontology which construed people without states as a source of threat to security. Even for a trenchant critic of European war-making such as Immanuel Kant (1724-1804), European states and their often bloody wars were considered far preferable to the condition exemplified by 'state-less', 'savage' peoples.

In his Anthropology from a Pragmatic Point of View, Kant summarised his philosophy of human development. For him, purposive human self-development was driven not simply by human reason, but by the genius of nature: 'Nature has planted in the species the seed of discord, and ... nature has willed that the common species, through its reason, turn discord into concord or at least a constant approximation of it'.29 In other words, competition and conflict between human 
beings (individuals, communities, and nations) spurs the use of reason to search for ever better solutions to conflict, leading inevitably to the development of 'culture', civil society and states. For Kant, this process of 'becoming civilized through culture' involved personal moral development 'from the crudity of mere self-reliance to a well-mannered (but not yet moral) being bent on concord'. ${ }^{30}$ The key part of this process, Kant argued, was that reason would incline individuals to live in society in which the individual 'has to cultivate himself, civilize himself, and apply himself to a moral purpose by [education in] the arts and sciences.' ${ }^{31}$ Kant was very clear however, that not all forms of social life were worthwhile:

Man was not meant to belong to a herd like the domesticated animals, but rather, like the bee, to belong to a hive community. It is necessary for him always to be a member of some civil society. ${ }^{32}$

In this way, Kant linked human development not simply to the development of society, but to the development of civil societies based on property ownership, industrious activity, and secured by sovereign states. ${ }^{33}$

Just as Kant identified striving between individuals as the motor force behind the emergence of greater concord through society and culture, so striving between states, by which he meant war, would lead to greater international concord.

Kant went on to describe this process in terms of his 'herd and hives' and analogy: many such hives next to each others will soon carry on feuds as robber bees do (war). But robber bees do not do this for the same reason as men, namely, to strengthen themselves by uniting with others-for here the comparison ends ... Each people seeks to strengthen itself by the subjugation of its neighbours, either through the desire to expand or the fear of being swallowed up by the other ... Therefore civil or foreign war in this species [humans], as great an evil as it may be, is yet at the same time the mainspring for the transition from the crude state of nature to the civil state. ${ }^{34}$

It was for this reason that Kant would describe warfare as 'the mechanical device of Providence', a means by which 'struggling forces weaken each other through friction' and thereby gradually come to a greater awareness of the need to avoid conflict and seek ever-greater integration and security. Thus, the individual in Kant's scheme may be said to be dying for security in a double sense. As an individual in the 
state of nature he or she is perennially subject to the violence of others; as a lawabiding subject of a sovereign state, the individual is subjected to the awesome violence of the war-making sovereign state.

Kant's resolution of the apparent tension between the ultimate aim of peace and integration, and the present reality of war and international conflict, developed largely in response to Jean-Jacques Rousseau's famously pessimistic assessment of the Abbè St-Pierre's argument for 'perpetual peace' in Europe through the formation of a Europe-wide confederation. ${ }^{35}$ Rousseau's argument was that St-Pierre's project was an unrealistic fantasy; the sovereigns of European states were simply too jealous of their power, a power asserted and sustained though incessant warfare, to give any away to a confederal authority. ${ }^{36}$ For Kant, however, the mutually antagonistic relations between states in the international state of nature would thrust the process of social and moral concord and integration onto the global stage. Kant held, contra Rousseau, that a perpetual peace between individual states driven by incessant competition and violent conflict was not only desirable but possible as well. The thrust of Kant's argument consisted in the identification of a process of historical development, or in his terminology 'enlightenment', which 'must gradually spread upwards towards the thrones and even influence ... principles of government.' 37 As enlightenment spread, warfare would increasingly be seen as injurious to 'all trades and industries, and especially to commerce' and it was mainly on this argument that Kant's opposition to war rested. ${ }^{38}$ Reflecting Montesquieu's conception of commerce as a peaceful activity, Kant suggested that the 'spirit of commerce ... [could] not exist side by side with war' and that states must realise that their own 'financial power' depended upon preventing war with other commercial states. ${ }^{39}$

Kant (as well as Locke), transformed Hobbes's hypothetical death scene in an important way. For Kant, the problem of in/security resides in the perpetual fear of an 'unjust enemy' who lives in the license of savagery; who 'by word or deed' makes 'peace among nations ... impossible' and thereby 'perpetuate' a 'state of nature'. ${ }^{40}$ Though Kant does not specify who this 'unjust enemy' is, like Locke before him the implication is clearly that an objective distinction is made here between zones of security and insecurity. The problem of in/security is thus more a matter of confrontation between these zones, rather than (as it was for Hobbes) an 
internalised fear of the sovereign's death. The power of Hobbes's hypothetical death scene is sustained by Kant in the perpetual fear of an eruption of the state of nature and an ending of security. Kant's 'unjust enemy' is thus an abstract embodiment of the very same fear that Hobbes expressed in his hypothetical death scene, and that Locke conveyed in his account of a veritable state of nature in America.

For Kant, states were much more than protective institutions. States were the embodiment of 'right', the principles by which individuals accepted restrictions upon their liberty 'so that it harmonises with the freedom of everyone else'.41 Crucially, these principles could only be developed through instruction and correction in civil society under the guidance of sovereign authority. 42 The transition individuals undergo from the state of nature to the civil state is repeatedly described by Kant in terms of the renunciation of a 'lawless state of savagery' or the 'purposeless state of savagery'.43 For Kant, then, individual states in the international sphere occupied an analogous position to individual human beings in the state of nature. ${ }^{44}$ States, in other words, would be compelled through brute necessity and naked self-interest to 'make exactly the same decision ... as that which man was forced to make, equally unwillingly, in his savage state-the decision to renounce his brutish freedom and seek calm and security within a law-governed constitution'.45 An international civil society was conceived as a 'kind of league' or 'pacific federation' which, unlike a world government, did not possess coercive powers and, unlike a mere treaty which 'terminate[d] one war', the pacific federation sought 'to end all wars for good'. ${ }^{46}$ In a state of nature, as for example in relations among sovereign states before the creation of a 'pacific federation', there is no source of authority to curb war. Thus, there would be only one way of deciding disputes, by:

a war of extermination, in which both parties and right itself might all be simultaneously annihilated, would allow perpetual peace only on the vast graveyard of the human race. ${ }^{47}$

Kant's comment here reminds us that for him, 'civilized' forms of war involve the augmentation of state power. This latter kind of war is a double-edged weapon. On the one hand, it strengthens the hand of states and thus consolidates their position; on the other, it makes longer, larger and bloodier wars possible. Kant was hardly alone among European Enlightenment thinkers to make this observation. ${ }^{48}$ But even 
with the obvious cost of war between states, Kant nonetheless held that they were at least able to come to minimal agreements to regulate their interaction and warfare (the 'preliminary articles of a perpetual peace between states'), which could provide the foundation for later substantive principles (the so called 'definitive articles of a perpetual peace between states') aimed at finally eliminating war. Among these crucial 'preliminary articles' were agreements to avoid 'dishonourable stratagems' in war, such as espionage, poisoning or assassination. ${ }^{49}$ In arguing so, Kant gave voice to a widespread view in Enlightenment European thought that 'honour' was becoming the hallmark of the European way of war. 50

In the European imagination, then, the subject of security was couched in terms of sovereign state formation, and even war making. Although these states held a lethal power of command over their subjects, civilised conventions of war were thought nonetheless to protect and enhance the rights of those same subjects to security of person and property. By the eighteenth century, many European thinkers were coming to see the European way of war as a carefully structured and tightly controlled activity under the auspices of sovereign states. The celebration of this European way of war emphasised its industrial and technological sophistication, its complex organisation, its moderation of violence (for example, in sparing prisoners of war), and its rationality. Above all, European war was identified with the considered pursuit of security, while the 'savage' way of war was characterised by the festering rancour fuelling an incessant cycle of revenge culminating in the desire to annihilate one's enemies. ${ }^{51}$ By this means, Europeans were able to convince themselves, in the face of the terrible violence of European war-making, that the civilized subject of sovereign states, unlike so-called 'savages' living in the 'state of nature', was not dying for security. That they could do so was testament to the potency of fears of insecurity in the state of nature that Hobbes had given such memorable expression to in his hypothetical death scene. Subsequent thinkers such as Locke and Kant posed the problem of in/security without recourse to Hobbes's death scene but they sustained the same fear that insecurity threatened in the confrontation between 'civilised' zones of security and the 'savage' state of nature. ${ }^{52}$ 
—RECONCILING SECURITY IN COLONIAL AUSTRALIA

This kind of confrontation occurred in a variety of colonial settings in which Indigenous inhabitants were routinely cast as 'savages' whose condition was often characterised as a 'state of nature'. It has been tempting for historians to interpret the incidence of colonial violence in Australia and elsewhere as a problem of insufficient regulation of the frontier. In arguing so, it is as if Hobbes's hypothetical death scene were being played out again; frontier violence was a consequence of a lack of sovereignty and hence an absence of security (for settlers and Indigenous peoples). Frontier violence, however, can also be interpreted as an effect of the declaration of a sovereignty in which those deemed to be in a 'state of nature' were seen as a threat to those seeking the security of 'civilisation'.

In establishing the first permanent European settlement in Australia in 1788, Governor Phillip was instructed to 'conciliate' the 'affections' of the Indigenous inhabitants. ${ }^{53}$ Considerable doubt persists over what 'conciliation' might have meant, or how it might have been obtained, but many historians persist in interpreting it as an effort to win Indigenous 'friendship' through the application of British law. ${ }^{54}$ In these accounts of Australia's early colonisation, Phillip emerges as the agent of a peculiarly British colonial policy, which, from 1788, centred on the extension to Aboriginal peoples of the legal status of British subjects. ${ }^{55}$ This interpretation overlooks the small matter of the wording of the instructions. Far from extending British subject status to the Indigenous inhabitants, the instructions in fact enjoined the governor to use 'every possible means' to ensure that 'all our subjects' live 'in amity and kindness with them [the Indigenous inhabitants]'. ${ }^{56}$ From 1788 Indigenous Australians found themselves in fact to be anomalous subjects, neither voluntarily conciliated nor involuntarily subjugated by conquest. ${ }^{57}$ The result was that they found themselves embroiled in the perennial problem of in/security; lacking subject status they could not receive the protection of British law, and were thus subjected to the extra-legal violence of the colonial state.

The earliest accounts of the colonisation of Australia testify to the rapidity with which efforts to 'conciliate' the 'affections' of the Indigenous peoples degenerated into outright violence. Inevitably, the policy of conciliation soon became a policy to 'reconcile' the Indigenous people to living with the colony. This is how Phillip himself expressed it, claiming that he wanted to prevent abuses against 
the Indigenous people and to 'reconcile' them to 'live amongst us' so that they may be taught 'the advantages they will reap from cultivating the land' enabling them to 'support themselves'. ${ }^{58}$ Indeed, Governor Phillip tacitly admitted that the Indigenous people of Australia had been involuntarily subjected to British rule when he expressed his determination 'if possible' to bring the 'native inhabitants' to 'a voluntary subjection'.59

It was not until 1837 that an official pronouncement was made that the Indigenous inhabitants of Australia were regarded by Her Majesty's Government as British subjects entitled to full rights and protection under British law. The high sounding words, however, merely cast the problem of colonial insecurity in terms of the survival of the state of nature as then governor of New South Wales, George Gipps, tried to explain to Lord Glenelg at the Colonial Office:

If proprietors, for the sake of obtaining better pasturage ... will venture ... to such a distance from protection, they must be considered to run the same risk as men would do who were to drive their sheep into a country infested with wolves, the Government would encourage the shepherds to combine and destroy them, whilst all we can now do is, to raise, in the name of justice and humanity, a voice in favour of our poor savage fellowcreatures, too feeble to be heard at such a distance. 60

In 1840, the Colonization Commissioners for South Australia went further by warning that it was 'indefensible' to 'subject savage tribes to the penalties of laws with which they are unacquainted, for offences which they may possibly regard as acts of justifiable retaliation for invaded rights'.61 The question for them was how to effect an Indigenous subjection. In the process, Indigenous Australians found that it was they who were dying for security.

When twenty-six survivors of the Maria shipwreck on South Australia's south coast were killed by Indigenous people (belonging to the Milmenrura clan of the Ngarrindjerri people) in July 1840, South Australia's Governor Gawler dispatched a party of men under the command of the police commissioner, Major O'Halloran, to the scene.62 According to Indigenous tradition, the killings were prompted by some of the survivors abrogating Indigenous laws, possibly by assaulting Indigenous women.63 But so far as the colonial authorities were concerned this was a case of violence that had to be punished. Gawler's instructions 
authorised O'Halloran to apprehend the guilty parties of the so-called 'Big Murray tribe', and to explain to them that 'your warfare' is not with the whole tribe but only with those guilty of the murders, and that he and his men would 'not be held blameable' if he had to use 'extreme force' in the 'deliberate execution' of 'strictest justice'.64 Having apprehended two Indigenous men and convened a cursory 'court', O'Halloran found that 'neither of the culprits denied, though they would not actually confess their guilt', and he therefore sentenced them to death. ${ }^{65}$ O'Halloran then warned the remaining members of the 'Big Murray Tribe' that such was 'how the white man punished those who murdered any of his tribe'.66

In the face of public criticism in the colony of both the governor's authorisation and O'Halloran's actions, Gawler attempted to justify himself on the grounds that the Indigenous people in that part of the colony were "beyond the reach of the ordinary British law'. Gawler's reasoning was supported by the advocate general, Charles Cooper, whose long remarks on the case declared that:

The doctrine that they [the hostile Indigenous people] are to be held and dealt with as British subjects, and, under no circumstances, to be tried or punished, except according to the ordinary forms of law, cannot be received without modification. It may be true in its full extent, as regards those tribes with whom we have constant and peaceable intercourse ... [but those] who have never acknowledged subjection to any power ... however insignificant their numbers, or however savage and barbarous their manners [must be viewed] as a separate state or nation, not acknowledging, but acting independently of, and in opposition to, British interests and authority. ${ }^{67}$

The clear implication was made by Governor Gawler who saw Indigenous 'savagery' and British 'civilisation' as necessarily opposed conditions. The 'savagery' of Indigenous people discounted them from being accorded any significant rights at all, as subjects of their own state or nation, but especially as subjects of the British Crown. 68 The problem of in/security in the colonies was an effect of a sovereignty conceptualised in terms similar to those of Locke and Kant as a confrontation between civilised security and savage insecurity.

Captain George Grey succeeded Gawler as governor of South Australia in May 1841, and he, too, quickly became embroiled in the same difficulties his 
predecessor experienced. Publicly, the governor endorsed the official position that 'no belligerent rights [can be] exercised against the natives; and that no proceedings are adopted but such as the laws of England would authorise against an European who had been guilty of similar atrocities'. Privately, as Major O'Halloran recorded in a memorandum, Grey took a rather less scrupulous view of colonial security:

I asked the Governor what would be the extent of my powers and instructions if sent on such a service? Upon which he replied that I must treat the blacks if ... likely to resist as I would any other hostile party ... and that I should be fully justified in becoming the aggressors in such a case ... [and] should act with vigour until all resistance ceased. The Governor further added that tho the law might have to decide upon the legality of such proceedings, I might rest assured ... that the Government would give me every support and protection in their power. 69

\section{-CONCLUSION}

Australia's colonial past seems far removed from theoretical reflection on security. One connection between them, however, lies in the recent campaign for reconciliation between Indigenous and non-Indigenous Australians. Both this reconciliation vision of the nation, and the earlier security vision with which I began this article, envisage a cohesive Australian nation enjoying the fruits of shared citizenship and equal participation in Australia's democratic institutions. The 'moral force' of the reconciliation movement rests, as various writers have observed, on the 'acknowledgement' by non-Indigenous peoples that they bear a 'collective responsibility' to correct the 'wrongs committed by their political ancestors'. ${ }^{70}$ In moving his 'Apology to Australia's Indigenous Peoples', Kevin Rudd stated that 'the time has now come':

for the nation to turn a new page in Australia's history by righting the wrongs of the past and so moving forward with confidence to the future. We apologise for the laws and policies of successive Parliaments and governments that have inflicted profound grief, suffering and loss on these our fellow Australians. ${ }^{71}$ 
As he presented it then, the Apology was an essential step for Australians to 'become fully reconciled to their past' by dealing with 'unfinished business', removing a 'great stain from the nation's soul', thereby kindling a 'true spirit of reconciliation'.72

In the repeated invocation of reconciliation today can be heard the echoes of Governor Phillip's failure to obtain 'conciliation' in 1788. This conciliation, it will be remembered, was never a fair bargain, never an attempt to obtain 'consent', to negotiate over land or over sovereignty. Conciliation was a play for acquiescence in order to secure the lives and property of British subjects. Even when Indigenous Australians were given the dubious honour of being regarded Her Majesty's subjects, they did not receive protection because colonial officials still largely regarded them as subjects in name only. Civilisation, it seems, was a precondition for security, and Indigenous Australians were to find time and again throughout the nineteenth and into the twentieth century that in being found wanting against this artificial standard, they were entitled only to a precarious and heavily conditional security.

Europe's history of colonial and imperial definitions of security-as a condition that requires the elimination of 'savage' threats-continues to reverberate in contemporary global politics. Mgbeoji, for example, argues that the European imperial creation of 'order from the chaotic environment of the savage' still sustains the identification of the 'global South' (especially Africa and South Asia) as the main locus of threats to the security of the 'global North' (especially Europe and North America). ${ }^{73}$ According to Anghie the recent 'war on terror', ostensibly waged by the United States and its allies for greater security, was merely a 'new form of imperialism', a reiteration of the 'much earlier imperial ... civilising mission'.74 Some have therefore argued for a more inclusive notion of 'human security' that is less focused on sovereign states as the sole guarantors of security, seeking instead to elevate the suffering and the needs of individual persons as the sole object of all security mechanisms. ${ }^{75}$ As Youssef sees it, however, even the apparently 'humanitarian' construction of 'suffering humanity' in need of 'humanitarian intervention' serves merely to render the suffering as abject-in need of Western intervention but stripped of rights, identity and political equality. ${ }^{76}$

The problem then is less to do with narrow concepts of security (such as Hobbes's) being replaced by a broader, more 'humane' concept (such as human 
security). The problem relates to the very ontology of security; to the identification of who is to be secured from whom. The ontology of the subject of security is deeply embedded in Western thought. In this ontology, the subject of security is perpetually subject to the threat of insecurity. This threat was powerfully conceptualised by Hobbes in terms of his hypothetical death scene. Its long shadow in subsequent Western thought, however, is due less to the scene Hobbes portrayed, than to the transformation by subsequent thinkers such as Locke and Kant of the fear Hobbes's death scene conveyed of the insecurity of the state of nature. The problem of in/security consists in the targeting of violence and other coercive means at whomever appears as a threat to the subject of security. The problem of in/security underwrites the terrible paradox that the very being of the subject of security requires a perennial threat to their security-whether from the Indigenous inhabitants during Australia's colonisation or from those deemed to be terrorists today. Both are entwined in this ontological paradox, and both are dying for security.

Bruce Buchan is a political theorist whose work traces the historical articulation of key concepts in Western political philosophy. His recent publications include studies of civilization and savagery, society, war, the body politic and corruption. Currently he is working on an Australia Research Council Future Fellowship research project examining the historical articulation of the distinction between purportedly civilized or symmetrical war and supposedly savage or asymmetrical war.

\footnotetext{
-NOTES

Research for this essay was conducted for my ARC Future Fellowship project, 'A Colonial and Conceptual History of Asymmetric Warfare and Security', hosted by the ARC Centre of Excellence in Policing and Security, Griffith University. I would like to thank the participants at the Interrogating Death and Dying Symposium at the University of Sydney, especially Kristin Savell, Isabel Karpin, David Ellison and Margaret Gibson, but most of all Kathryn Seymour.
} 
${ }^{1}$ Hon. K. Rudd, PM, 'National Security Statement', House of Representatives Official Hansard, Thursday 4 December 2008, p. 12549.

2 Maisaa Youssef, 'Suffering Men of Empire: Human Security and the War on Iraq', Cultural Dynamics, vol. 20, no. 2, 2008, p. 155.

${ }^{3}$ Although Leviathan was composed during the horrors and instability of the English Civil War (164249), at the time of writing it Hobbes was resident in France during the civil unrest known as the Fronde (1649-52). Hobbes's obsession with security dates at least to his earlier Elements of Philosophy (1641), the last section of which (on politics) was published as De Cive in 1642. Richard Tuck, 'Introduction' to Thomas Hobbes, Leviathan [1651], R. Tuck (ed.), Cambridge University Press, Cambridge, 1996, pp. xxii, xix-xx.

${ }^{4}$ Bruce Buchan, “Dua pezzi in sulla piazza”: The Death of the Body Politic in Western Political Thought', South Atlantic Quarterly, vol. 110, no. 4, 2011 (forthcoming). Hobbes did claim that his own political theory illustrated the possibility of an 'everlasting' commonwealth. Hobbes, Leviathan, p. 232.

${ }^{5}$ Hobbes, Leviathan, p. 221.

${ }^{6}$ Hobbes, Leviathan, p. 221.

${ }^{7}$ Hobbes, Leviathan, p. 230.

8 'National Security Statement', Hansard, p. 12551. Anthony Burke makes a similar though different connection between Hobbes and Locke and modern American conceptions of freedom and security in his 'Freedom's Freedom: American Enlightenment and Permanent War', Social Identities, vol. 11, no. 4, 2005, pp. 327-8.

9 John Locke, Two Treatises of Government [1690], ed. P. Laslett, Cambridge University Press, Cambridge, 1988, II, §93, p. 328.

10 Quotes here are from: Thomas Starkey, A Dialogue Between Pole and Lupset [1529-32], (ed.) T.F. Mayer, Royal Historical Society, London, 1989, p. 67; and Thomas Smith, De Republica Anglorum [1583], Scholar Press, Menston, 1970, pp. 43-5. See also Rieko Karatani, Defining British Citizenship: Empire, Commonwealth and Modern Britain, Frank Cass, Abingdon, 2002, p. 17.

${ }^{11}$ Hobbes, Leviathan, p. 150. Quentin Skinner, 'States and the Freedom of Citizens' in Quentin Skinner and Bo Stråth (eds), States and Citizens: History, Theory, Prospects, Cambridge University Press, Cambridge, 2003, pp. 15-17.

12 Thomas Hobbes, On the Citizen [1641], ed. and trans. Richard Tuck and Michael Silverthorne, Cambridge University Press, Cambridge, 1998, p. 144.

13 Hobbes, On the Citizen, pp. 70, 78.

${ }^{14}$ Hobbes, On the Citizen, pp. 79. For the German Hobbesian, Samuel Pufendorf, the duty of subjects to obey their sovereign would even excuse the taint of unjust acts the sovereign commanded, such as participation in an unjust war. Samuel Pufendorf, The Whole Duty of Man According to the Law of Nature [trans. A. Tooke, 1691], eds Ian Hunter and David Saunders, Liberty Fund, Indianapolis, 2003, pp. 224-5. 
15 Hobbes, Leviathan, pp. 152 and see 147-8.

16 Hobbes, Leviathan, p. 150.

17 Hobbes, Leviathan, pp. 89-90, 153.

18 Hobbes, Leviathan, p. 126.

${ }^{19}$ Hobbes, Leviathan, p. 89.

20 Jonathan Scott, England's Troubles: Seventeenth Century English Political Instability in European Context, Cambridge University Press, Cambridge, 2000, pp. 286, 359-60, 384. Robert Filmer, Patriarcha [1680], in Johann P. Sommerville (ed.), Patriarcha and Other Writings, Cambridge University Press, Cambridge, 1991, pp. 7, 12.

21 Locke, Two Treatises, § 88 pp. 324-5.

22 Locke, Two Treatises, § 93 p. 238.

${ }^{23}$ Locke, Two Treatises, $§ 108$ p. 339-40.

${ }^{24}$ Locke, Two Treatises, $§ 212$ p. 407.

25 Hugo Grotius, The Law of War and Peace [1625], trans. F.W. Kelsey, Bobbs-Merrill, Indianapolis, 1925, Bk ii 186-90; also, Pufendorf, Whole Duty of Man, p. 129. John Salter, 'Hugo Grotius: Property and Consent', Political Theory, vol. 29, no. 4, 2001, pp. 544-5. According to Pagden, the crucial innovation of Grotius and later Natural Lawyers was to see human sociability (and hence the historical narrative about the development of civil societies) as originating in an 'act of will', whereas earlier Natural Lawyers saw human sociability as a natural attribute. Anthony Pagden, 'Human Rights, Natural Rights, and Europe's Imperial Legacy', Political Theory, vol. 31, no. 2, 2003, p. 180.

26 Paul Keal, European Conquest and the Rights of Indigenous People: The Moral Backwardness of International Society, Cambridge University Press, Cambridge, 2003, p. 26.

27 Alberico Gentili, De Juri Belli Libri Tres [1612], trans. J. Rolfe, Clarendon Press. Oxford, 1933, p. 12.

${ }^{28}$ John Arquilla, 'Realities of War: Global Development, Growing Destructiveness and the Coming of a New Dark Age?', Third World Quarterly, vol. 30, no. 1, 2009, pp. 69-80.

${ }^{29}$ Immanuel Kant, Anthropology from a Pragmatic Point of View, trans. V.L. Dowdell, Southern Illinois University Press, Carbondale, 1996, p. 238. Here and elsewhere I have retained Kant's gender-specific language in quotations from original sources.

${ }^{30}$ Kant, Anthropology, p. 240.

31 Kant, Anthropology, pp. 240-1.

32 Kant, Anthropology, p. 247.

33 Thus Kant's enthusiasm for the rule of Frederick II in 'An Answer to the Question: What is

Enlightenment?' [1784], in Hans Reiss (ed.), Kant's Political Writings, Cambridge University Press, Cambridge, 1970, pp. 58-9.

34 Kant, Anthropology, pp. 247-8.

35 Jean-Jacques Rousseau, A Project for Perpetual Peace, M. Cooper, London, 1761, pp. 19-21. 
36 Jean-Jacques Rousseau, Judgement on Perpetual Peace [1760], trans. Edith M. Nuttall, Richard Cobden-Sanderson, London, 1927; and Jean-Jacques Rousseau, 'The State of War', in Grace G. Roosevelt, Reading Rousseau in the Nuclear Age, Temple University Press, Philadelphia, 1990, p. 189.

37 Immanuel Kant, 'Idea for a Universal History With a Cosmopolitan Purpose' [1784], in Reiss (ed.), Kant's Political Writings, p. 51.

38 Kant, 'Universal History', p. 50; and Immanuel Kant, 'On the Common Saying: “This may be True in Theory, But it Does Not Apply in Practice"' [1792], in Reiss (ed.), Kant's Political Writings, p. 90.

39 Immanuel Kant, Perpetual Peace: A Philosophical Sketch [1795], in Reiss (ed.), Kant's Political

Writings, p. 114. Montesquieu had argued that commerce was an activity requiring more 'gentle [doux] mores', but as his subsequent remarks on Britain indicated, he also thought that commercial nations (republics) would be stronger and more secure than tyrannies. C-L.S. Montesquieu, The Spirit of the Laws [1748], edited and translated by Anne M. Cohler, Basia C. Miller, and Harold S. Stone, Cambridge University Press, Cambridge, 1989, pp. 338, 343-6.

40 Kant, 'Metaphysical First Principles of the Doctrine of Right', The Metaphysics of Morals, M. Gregor et al. (eds), Cambridge University Press, Cambridge, 1996, §60, p. 119. On Kant's 'unjust enemy' see C. Schmitt, The Nomos of the Earth in the International Law of the Jus Publicum Europaeum, translated by G.L. Ulmen, Telos Press, New York, 2003, pp. 168-71.

41 Kant, Theory and Practice, p. 73.

42 Kant, 'What is Enlightenment?', pp. 58-9.

${ }^{43}$ Kant, Universal History, pp. 47, 49.

${ }^{44}$ Kant, Theory and Practice, p. 90. Italics in original.

45 Kant, Universal History, p. 48.

46 Kant, Perpetual Peace, p. 104.

47 Kant, Perpetual Peace, p. 96.

48 See for example, Bruce Buchan, 'Civilization, State Sovereignty and War: the Scottish Enlightenment and International Relations', International Relations, vol. 20, no. 2, 2006, pp. 175-92.

${ }^{49}$ Kant, Perpetual Peace, p. 96.

${ }^{50} \mathrm{John}$ Adams, A Defence of the Constitutions of Government of the United States of America, C. Dilly, London, 1787-88, pp. 330-1; Montesquieu, Spirit of the Laws, 74-6; 82, 87; Richard Bourke, 'Edmund Burke and Enlightenment Sociability: Justice, Honour and the Principles of Government', History of Political Thought, vol. XXI, no. 4, 2000, pp. 632-56.

51 For a contemporary view of 'savage' war in America see, John Filson, The Discovery, Settlement, and Present State of Kentucke, James Adams, Wilmington, 1784, pp. 76, 80. It must be emphasised again that this image of 'savage' as opposed to 'civilized' war obscured both the intensified lethality of European wars, and the pursuit by Europeans of the annihilation of their 'enemies'.

52 On the 'state of nature' in Australia see David Collins, An Account of the English Colony in New South Wales [1798], Vol I, (facsimile, Libraries Board of SA, Adelaide, 1971), p. 544; and 'Governor Phillip to 
Lord Sydney, 15 May 1788'; 'Phillip to Secretary Stephens, 10 July 1788', Historical Records of Australia, I, pp. 26-30, 62.

53 'Governor Phillip's Instructions', Historical Records of Australia, series 1, volume 1, ed. F. Watson, Library Committee of the Commonwealth Parliament, Sydney, 1914, p. 13.

54 See for example, Alan Frost, Arthur Phillip 1738-1814. His Voyaging, Oxford University Press, Oxford, 1987, pp. 184;

55 Frost, p. 144. This formulation could be variously rendered as 'subjects of the crown', and 'Her' or 'His majesty's subjects'.

56 'Governor Phillip's Instructions', Historical Records, p. 13. (My italics).

${ }^{57}$ For Aboriginal people the appellation 'subject' may have served not only to signify their subjection to a foreign sovereign, but also to enable their claims on the crown for respect for their rights and land. This, I take it, is what Cooper means by his observation that 'external categorizations' imposed by colonial authorities 'have both stigmatized and humiliated people and given them an enabling and empowering sense of collective selfhood...'. Frederick Cooper, Colonialism in Question: Theory,

Knowledge, History, University of California Press, Berkeley, 2005, p. 85

58 'Phillip to Lord Sydney, 10 July 1788', Historical Records, I, p. 65. Later governors were also to express the desire to effect 'reconciliation'. See for example, The Sydney Gazette, 17 July 1805, in The Sydney Gazette and New South Wales Advertiser, vol III.

${ }^{59}$ Arthur Phillip, The Voyage of Governor Phillip to Botany Bay... [1789], facsimile, Libraries Board of SA, Adelaide, 1968, p. 68.

60 'Gipps to Glenelg 21 July 1838', in British Parliamentary Papers, Colonies Australia 5, Irish University Press, Shannon, 1970, p. 28. Gipps's comments here were also a response to the Myall Creek massacre (June 1838).

61 'Fourth Annual Report of the Colonization Commissioners for South Australia, 8 January 1840', Correspondence and Papers Relating to the Government and Affairs of the Australian Colonies 183740, BPP, Colonies Australia 5, p. 445.

62 Gawler informed London of this 'very serious outrage' and his determination to 'execute summary justice, after deliberate and formal investigation' on 15 August 1840, 'Gawler to Lord John Russell, 15 August 1840', CO 13/16.

63 Diane Bell, Ngarrindjeri Wurruwarrin: A World that Is, Was and Will Be, Spinifex Press, Melbourne, 1998, pp. 429-30. Two years previously members of the same clan had aided survivors from the Fanny shipwreck who spoke of the Indigenous peoples' aid and hospitality in glowing terms.

64 Gawler's instructions to O'Halloran, dated 14 August 1840, are also enclosed in 'Gawler to Lord John Russell, 5 September 1840', CO 13/16.

65 The transcript of O'Halloran's 'court' proceedings is terse, the Indigenous testimony is rendered into simple words and phrases, the testimony of the whole captive tribe is improbably reported as 
unanimous. The transcript is dated 24 August 1840 and is enclosed in 'Gawler to Lord John Russell, 5 September 1840', CO 13/16.

66 George French Angas recorded that members of the same tribe were wary of contact with whites in 1846. G.F. Angas, Savage Life and Scenes in Australia and New Zealand, vol. 1, Smith, Elder and Co, London, 1847, p. 133.

67 Taken from South Australian Gazette, 17 September 1840, p. 2, CO 16/1.

68 Taken from South Australian Gazette, 1 October 1840, p. 2. C0 16/1.

${ }^{69}$ Quotes here from, Colonial Secretary to O'Halloran, 4 November 1842; and O'Halloran's

Memorandum 18 April 1842.

70 Raimond Gaita, 'The Moral Force of Reconciliation', and P. Dodson, 'Whatever Happened to Reconciliation?' both in J. Altman and M. Hinkson (eds), Coercive Reconciliation. Stabilise, Normalise, Exit Aboriginal Australia, Arena Publications, North Melbourne, 2007, pp. 21 and 300-1.

${ }^{71}$ Hon. K. Rudd, PM, 'Apology to Australia's Indigenous Peoples', House of Representatives Official Hansard, Wednesday 13 February 2008, p. 167.

72 Rudd, 'Apology', Hansard, p. 167.

73 Ikechi Mgbeoji, 'The Civilised Self and the Barbaric Other: Imperial Delusions of Order and the Challenges of Human Security', Third World Quarterly, vol. 27, no. 5, 2006, pp. 858, 856.

${ }^{74}$ Antony Anghie, 'The Evolution of International Law: Colonial and Postcolonial Realities', Third World Quarterly, vol. 27, no. 5, 2006, p. 750.

75 See for example, Shahrbanou Tadjbakhsh and Anuradha M. Chenoy, Human Security: Concepts and Implications, Routledge, London, 2007, pp. 13, 58.

76 Youssef, 'Suffering Men of Empire', p. 163. 